\title{
Study on the Effect of Varun Twak Lepa in Management of Vyanga
}

\author{
Research Article
}

\section{Swati Shivaji Mundhe ${ }^{*}$, Vinod Ade ${ }^{2}$}

\author{
1. Assistant Professor Department of Swasthvritta, 2. Professor, Department of Kayachikitsa, \\ Mahatma Gandhi Ayurved College Hospital And Research Centre, Salod (H), Wardha
}

\begin{abstract}
Vyanga is a disease, which decreases the glowing complexion of the face and affects the skin. Among many diseases concerned with the cosmetic values, Vyanga is common disease one of them known to us from thousands of years. Acharya Sushruta and Vagbhatta has mentioned Vyanga as Kshudra Roga. Though it is considered as Kshudra Roga(minor disease), but it has got a major importance as a cosmetic problem in the society. Vyanga can be correlated with melasma, it is the common pigmentary disorder characterised by symmetrical hyper pigmented macules on face. Aim-To study on the effect of Varun Twak Lepa in management of Vyanga. In this study, the trial drugs used were Varun Twak Lepa for topical application. Material and methods- A total 40 patients of Vyanga were selected from OPD and IPD of Kayachikitsa. Observation and results- To study the effect of Varun Twaka Lepa assessment of patient were done on the basis of MSI score. In all three types, dermal, epidermal and mixed significant result was found on $20^{\text {th }}$ and $30^{\text {th }}$ day. In comparison of three types of melasma more significant result was found in epidermal type.
\end{abstract}

Key Words: Vyanga, Kshudra Roga, Melasma, Varun Twaka Lepa.

\section{Introduction}

Beauty is one of the most valued aspect in this competitive era. The importance of beautiful and healthy skin is increasing day by day. Any unhealthy state of physique is reflected by the skin as beauty is manifested by complexion. Vyanga is a disease, which decreases the glowing complexion of the face and affects the skin. Among many diseases concerned with the cosmetic values, Vyanga is common disease one of them known to us from thousands of years. Acharya Sushruta and Vagbhatta has mentioned Vyanga as Kshudra Roga.(1,2) And Acharya Charak has mentioned it as Raktapradoshaj Vikar.(3) Though it is considered as Kshudra Roga(minor disease), but it has got a major importance as a cosmetic problem in the society. It is characterized by the presence of Niruja (painless), Tanu (thin) and Shavavarna Mandalas (bluish-black patches) on face. (4) As per Acharya Sushruta, Krodha and Ayasais the main cause of Vyanga,(5) this is supported by Madhavnidan(6) and Yogratnakar (7) too. By Acharya Vagbhatta, Krodh and Shok is the cause of Vyanga which leads to vitiation of Vata, Pitta followed by Rakta Dosha.(8) Acharya Vagbhatta also explained the types of Vyanga they are Vatik, Paittik, Kaphaj and Raktaj.(9)

\section{* Corresponding Author:}

\section{Swati Shivaji Mundhe}

Assistant Professor, Department of Swasthvritta, Mahatma Gandhi Ayurved College Hospital And Research Centre, Salod (H), Wardha, 442001, Maharashtra, India

Email Id: swatishivajim90@gmail.com
As per Modern science, Vyanga can be correlated with melasma, it is the common pigmentary disorder characterised by symmetrical hyper pigmented macules on face. It mainly affect the women at reproductive age who having Fitzpatrick skin type 4-6 and in darker types of skin like Asian, Africans, Hispanics and Americans.(10) The ateopathogenesis of Melasma includes ultraviolet radiation, birth control pills, some phototoxic topical or systemic medications, hormonal disturbances, cosmetics and genetic factors. (11) There are only three patterns of melasma, centrofacial, malar and mandibular and centrofacial pattern is the commonest one.(12) As per studies it is most common pigment disorder in Indians. In South East Asia , in dermatology clinics it accounting $0.25 \%$ to $4 \%$.(13) Though it is predominantly found in females but males are also affected, in India, female is to male ratio is $4: 1$.(14) Pregnant women can get affected $50 \%$ to $70 \%$ and post pregnancy period is the most common time of onset of melasma.(15) Management of melasma includes Hydroquinone, corticosteroids, tretinoin, azelaic acid, chemical peeling, laser therapy. These are effective but it also causes more adverse effects on skin like irritation, erythema, cracking, PIH and prolonged dyschromia.(16) Apart from this, it is expensive, so considering this drawbacks there is need to search better method of management.

In Ayurveda many Chikitsa are explained for Vyanga by different Acharyas. These are Lepa, Abhyanga, Raktamokshan, Virechan, Nasya and Shaman aushadhi. Lepa is one among them and it is more effective, as it is directly acts on lesion.

\footnotetext{
Aim and Objectives

Aim of study

"Study on the effect of Varun Twak Lepa in management of Vyanga".
} 
Objectives of study

- To study the changes in MSI (Melasma Severity Index) in area of involvement and pigmentation.

\section{Material and Method}

Source of material

- Clinical source: The patients which fulfilling the clinical criteria of Vyanga were selected from OPD and IPD of Kayachikitsa department..

- Drug source: The raw drug of Varun was collected from field and identified by Department of Dravyaguna. Aja kshir ( Goats milk) was collected from local source and authenticated by Department of Rasashastra and Bhaishajya kalpana.

Table No. -1: Drug review:-Varun twak lepa (Ref-Chakradatta, Chapter- Kshudra Rogachikitsa)

\begin{tabular}{r|l|l} 
Sr. no. & Contents & Part used \\
1 & Varun (Crataeva nurvala linn.) & Stem bark \\
2 & Aja kshir (Goats milk) & Milk
\end{tabular}

- Method of preparation of drug:- Fine powder of Varun Twak was made. After that it was triturated with sufficient quantity of Aja kshir. Then it was dried properly and fine churna was made which was then preserved in airtight container.

- Ethics committee approval:- Before commencement of study, it was approved by Institutional Ethics Committee (reference no. DMIMS (DU)/IEC/ 2017-18/6394) on dated 30 March 2017

- Study Design: Single arm interventional study

\section{Inclusion criteria:}

- Patients irrespective of sex, religion, occupation, and chronicity less than 5 years were selected for the study.

- Patients among the age group of 20-50 years were selected for the study.

- Patients with clinical features of Vyanga as per Ayurvedic classics were included.

\section{Exclusion criteria:}

- Hyper pigmentation caused due to any known cases of systemic disease like Addison's disease, Cushing's syndrome.

- Hyper pigmentation since birth like Neavus of Ota.

- Hyper pigmentation caused by tumours like malignant melanoma.

- Patient suffering with systemic disorders like renal failure, hepatic disorder.

\section{Withdrawal criteria}

- If any type of side effect were observed during study.

- If aggravation of symptoms occurred.

- If patient is not having the desire to continue the treatment.

\section{Methodology}

Patients from the OPD and IPD of Kayachikitsa department who having the clinical features of Vyanga (Melasma) were selected for the study. The patients were selected by irrespective of their sex, religion and occupation. Before participation in the study informed consent was obtained. Total 42 patients were registered as per the inclusion criteria and out of these, 40 patients had completed the study. All patients were examined by Wood's Lamp to assess the depth of pigmentation (Dermal/ Epidermal/Mixed).

\section{Posology}

Sufficient quantity of Varun Twak Lepa was given for local application once in a day for 30 days.

\section{Method of application of Lepa}

Patient was advised to clean face properly. Then take Lepa churna and make paste of it with water. Apply sufficient quantity over affected area for 20 minutes and then wash the face properly with water. The Lepa was applied once in a day for 30 days.

\section{Assessment Criteria}

- The assessment of patient was made on basis of MSI score on $0^{\text {th }}, 10^{\text {th }}, 20^{\text {th }}$ and $30^{\text {th }}$ day.

Melasma Severity Index score (17)

Table No. :-2 Gradation of the area involved

\begin{tabular}{c|c|}
\hline Grade & Area Involvement (A) \\
0 & $<10 \%$ area involved \\
1 & $11-30 \%$ area involved \\
2 & $31-60 \%$ area involved \\
\hline 3 & $>60 \%$ area involved \\
\hline
\end{tabular}

Table No:- 3 Gradation of severity of pigmentation

\begin{tabular}{|c|c|}
\hline Grade & Pigmentation \\
0 & No visible pigmentation \\
1 & Barely visible pigmentation \\
2 & Mild pigmentation \\
3 & Moderate pigmentation \\
\hline
\end{tabular}

The MSI score is calculated by applying following formula

MSI $=0.4\left(a \times p^{2}\right) 1+0.4\left(a \times p^{2}\right) r+0.2\left(a \times p^{2}\right) n$

"a" - area of involvement; "p" - severity of pigmentation; "l" - left side of face; "r" - right side of face; " $n$ "-nose.

\section{Observation and Result}

This study was conducted to study the result of Varuntwak Lepa in the management of Vyanga. Total 40 patients were participated in this study. it was single group study. In the Microsoft Excel Worksheet obtained data was coded and entered. Statistical analysis was done on the basis of descriptive and inferential statistics by using student's paired t test. The software used in the analysis was SPSS 22.0 version and $p<0.05$ is considered as level of significance. 
Age wise distribution of patients

As per age wise distribution, more patient (40\%) was from 41-50 yrs group and comparatively less than that (37.5\%) was from 31-40 yrs age group.

\section{Graph 1:- Age wise distribution of patients}

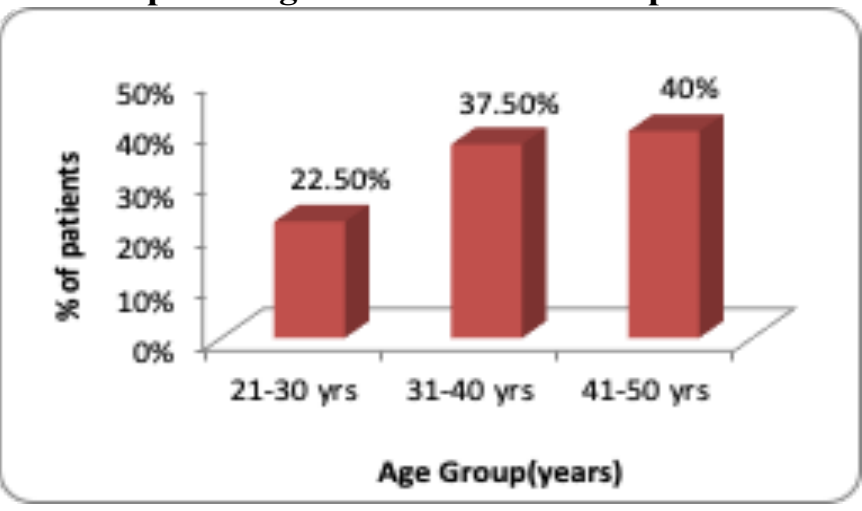

Distribution of patients as per gender

Distribution of patient as per gender shows that there were $34(85 \%)$ female and $6(15 \%)$ male.

\section{Graph 2: Distribution of patients as per gender}

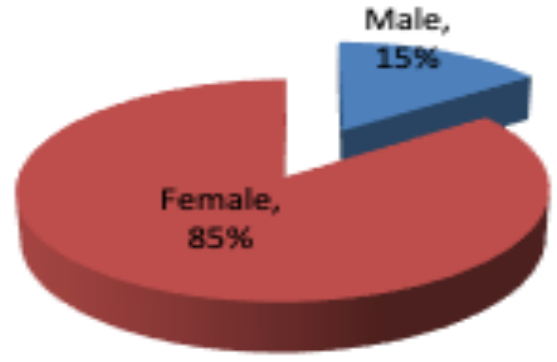

Distribution of patients according to duration(years) Distribution of patients shows that $27.5 \%$ of patient having chronicity of disease upto 1 year. $25 \%$ of patient from 1.1 -2 year and again 25\% was from 2.1-3 year. $15 \%$ was from $3.1-4$ year and $7.5 \%$ was from $4.1-5$ year.

\section{Graph 3: Distribution of patients according to} duration(years)

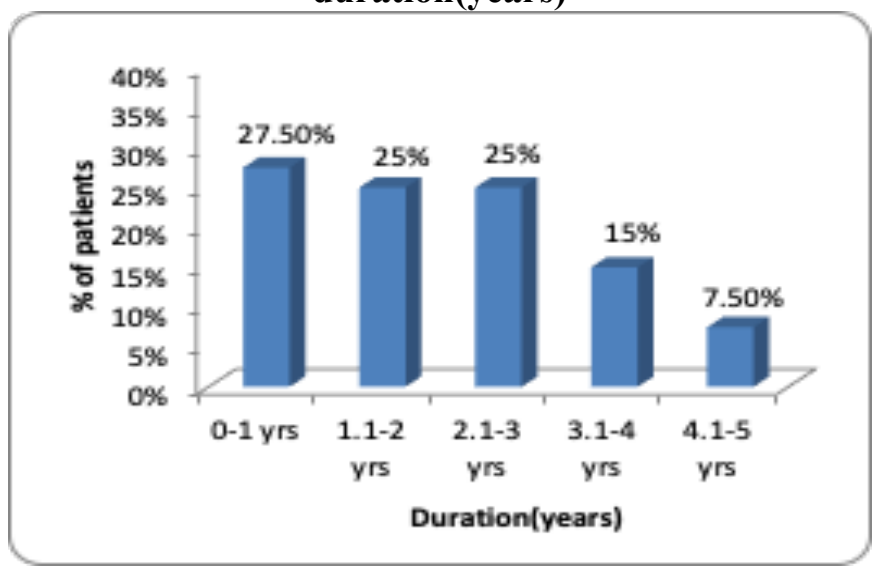

\section{Distribution of patients as per family history}

Out of 40 patients , 16 patient (40\%) having family history of Melasma where 24 patient (60\%) not having such type of history.

\section{Graph 4: Distribution of patients as per family history}

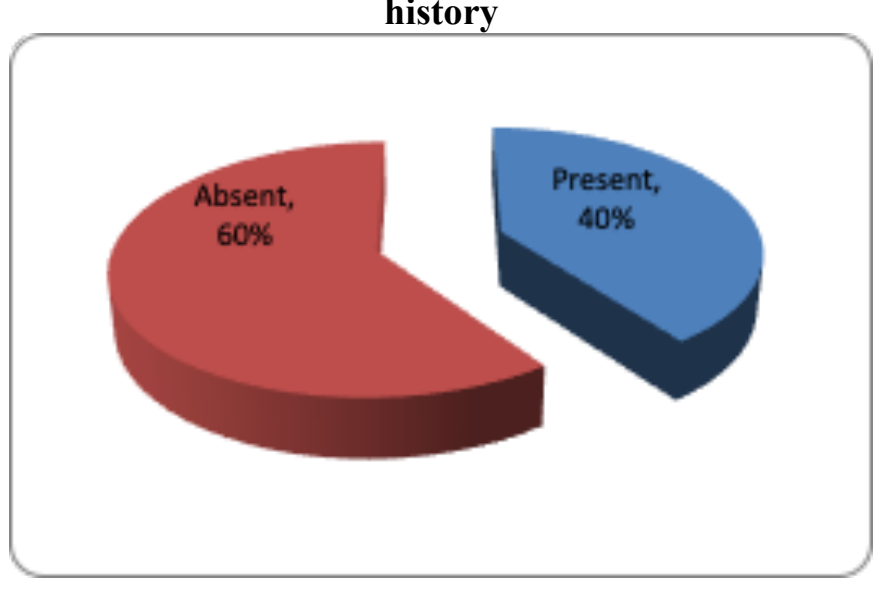

Distribution of patients according to type of Ahar

As per distribution of patients according to Ahar, there were 23 patients $(57.5 \%)$ having mixed and 17 patients $(42.5 \%)$ having vegetarian diet.

Graph 5: Distribution of patient according to type of Ahar

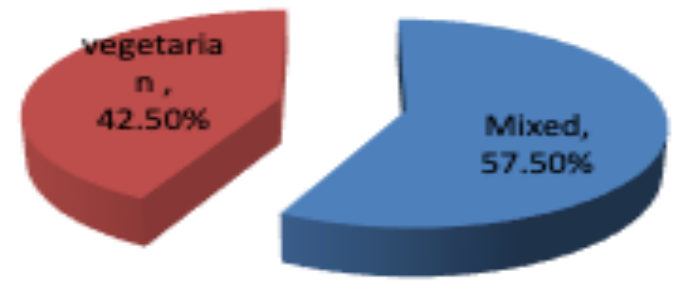

Sun Exposure wise distribution of patients

This table shows that, 18 patient $(45 \%)$ were having history of regular sun exposure while 22 patient $(55 \%)$ had no history of regular sun exposure.

Graph 6: Sun Exposure wise distribution of patients

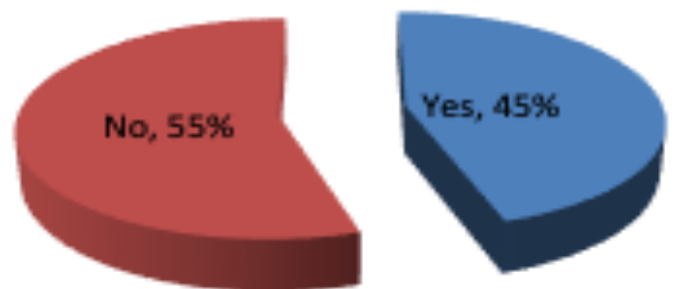


Distribution of patients as per Cosmetic use

As per above table there were 18 patient (45\%) having history of regular cosmetic use while 22 patient $(55 \%)$ had no history of cosmetic use.

\section{Graph 7 : Distribution of patients as per} Cosmetic use
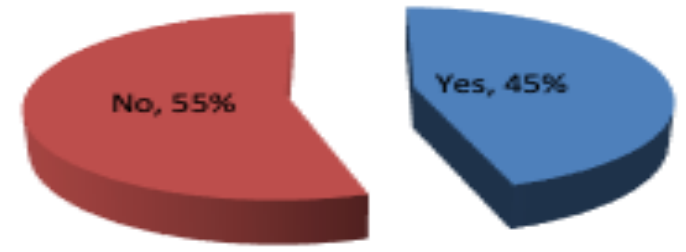

\section{Prakruti wise distribution of patients}

In the categorization of Sharir Prakruti, $35 \%$ patients were of Pittakaphaj Prakruti, and 30\% patients were of vatapittaj, $25 \%$ patients were of Pittavataj, comparatively less number of patient $10 \%$ were of Kaphapittaj.

\section{Graph 8: Prakruti wise distribution of patients}

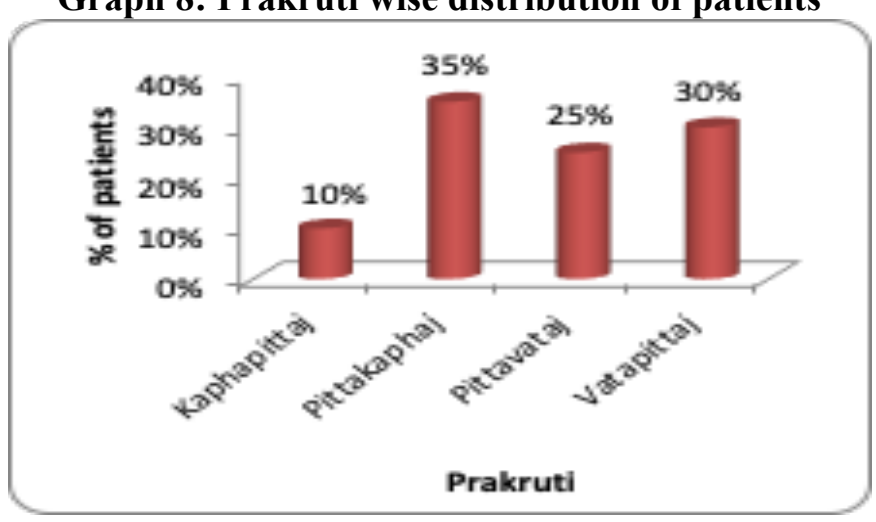

Distribution of patients according to Wood's lamp examination

The types of Melasma was diagnosed with the help of Wood's lamp exam. In this study, there were 14 patient $(35 \%)$ of epidermal, 14 patient $(35 \%)$ of mixed and 12 patient (30\%) of dermal type.

Graph 9: Distribution of patients according to Wood's lamp examination

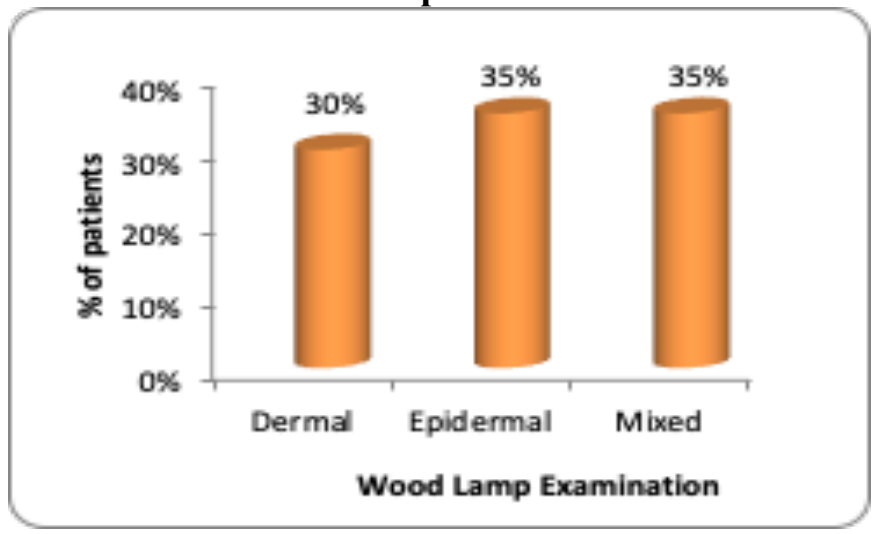

Distribution of patients as per clinical pattern

There are three facial patterns of Melasma centrofacial, malar and mandibular. In this study there were 20 patient $(50 \%)$ of centrofacial, 17 patient $(42.5 \%)$ of malar comparatively very less 3 patient $(7.5 \%)$ of mandibular observed.

Graph 10: Distribution of patients as per clinical patterns

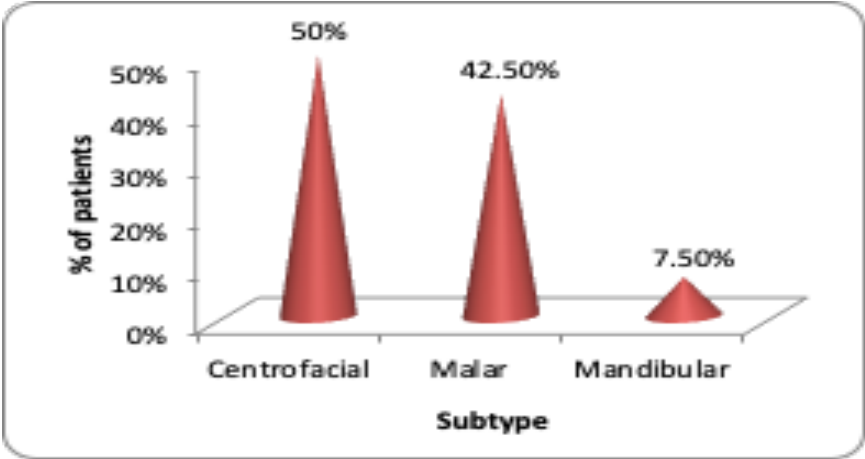

Comparison of MSI score with baseline : Dermal (Student's paired t test)

\begin{tabular}{|l|l|l|l|l|l|l|l|}
\hline & Mean & N & Standard deviation & Standard Error Mean & Mean difference & t- value & p value \\
\hline Baseline & 10.46 & 12 & 3.62 & 1.04 & - & - & \\
\hline $\mathbf{1 0}^{\text {th }}$ day & 10.46 & 12 & 3.62 & 1.04 & - & - & \\
\hline $\mathbf{2 0}^{\text {th }}$ day & 6.93 & 12 & 3.82 & 1.10 & $3.53 \pm 1.30$ & 9.35, & $\mathrm{p}=0.0001, \mathrm{~S}$ \\
\hline $\mathbf{3 0}^{\text {th }}$ day & 5.41 & 12 & 3.38 & 0.97 & $5.05 \pm 1.53$ & 11.41, & $\mathrm{p}=0.0001, \mathrm{~S}$ \\
\hline
\end{tabular}

The mean MSI score in dermal type of patient was 10.46 then $10.46,6.93,5.41$ on baseline, $10^{\text {th }}$ day, $20^{\text {th }}$ day and $30^{\text {th }}$ respectively. Significant result was observed on $20^{\text {th }}$ day and $30^{\text {th }}$ day.

Comparison of MSI score with baseline: Epidermal (Student's paired t test)

\begin{tabular}{|l|c|c|c|c|c|c|c|}
\hline & Mean & $\mathbf{N}$ & Standard deviation & Standard Error Mean & Mean difference & t-value & p-value \\
\hline Baseline & 5.72 & 14 & 3.94 & 1.01 & - & - & \\
\hline $\mathbf{1 0}^{\text {th }}$ day & 5.72 & 14 & 3.94 & 1.01 & - & - & \\
\hline $\mathbf{2 0}^{\text {th }}$ day & 3.80 & 14 & 2.99 & 0.77 & $1.92 \pm 1.89$ & 3.92 & $\mathrm{p}=0.002, \mathrm{~S}$ \\
\hline $\mathbf{3 0}^{\text {th }}$ day & 2.13 & 14 & 2.08 & 0.53 & $3.58 \pm 2.45$ & 5.65 & $\mathrm{p}=0.0001, \mathrm{~S}$ \\
\hline
\end{tabular}


The mean MSI score in epidermal type of patient was $5.72,5.72,3.80$ and 2.13 on baseline , $10^{\text {th }}$ day, $20^{\text {th }}$ day, and $30^{\text {th }}$ day respectively. Significant result was observed on $20^{\text {th }}$ and $30^{\text {th }}$ day.

\section{3: Comparison of MSI score with baseline: Mixed (Students paired $t$ test)}

\begin{tabular}{|l|c|c|c|c|c|c|c|}
\hline & Mean & $\mathbf{N}$ & Standard deviation & Standard Error Mean & Mean Difference & t-value & P value \\
\hline Baseline & 14.07 & 14 & 11.80 & 3.27 & - & - & \\
\hline $\mathbf{1 0}^{\text {th }}$ day & 13.27 & 14 & 9.97 & 2.79 & $0.80 \pm 2.34$ & 1.22, & $\mathrm{p}=0.243, \mathrm{NS}$ \\
\hline $\mathbf{2 0}^{\text {th }}$ day & 10.03 & 14 & 8.81 & 2.44 & $4.04 \pm 3.82$ & 3.81 & $\mathrm{p}=0.002, \mathrm{~S}$ \\
\hline $\mathbf{3 0}^{\text {th }}$ day & 6.52 & 14 & 5.46 & 1.51 & $7.55 \pm 8.53$ & 3.19, & $\mathrm{p}=0.008, \mathrm{~S}$ \\
\hline
\end{tabular}

The mean MSI score in mixed type of patient was $14.07,13.27,10.03$ and 6.52 on baseline, $10^{\text {th }}$ day, $20^{\text {th }}$ day, and $30^{\text {th }}$ da on baseline, $10^{\text {th }}$ day, $20^{\text {th }}$ day, and $30^{\text {th }}$ day respectively. Significant result observed on $20^{\text {th }}$ and $30^{\text {th }}$ day

\section{Comparison of data of MSI score with baseline (Student's paired t test)}

\begin{tabular}{|c|c|c|c|c|c|c|c|}
\hline & Mean & N & Standard Deviation & Standard Error Mean & Mean Difference & t-value & p value \\
\hline Baseline & 9.86 & 40 & 8.04 & 1.27 & - & - & \\
\hline $\mathbf{1 0}^{\text {th }}$ day & 9.60 & 40 & 7.09 & 1.12 & $0.26 \pm 1.35$ & 1.21, & $\mathrm{p}=0.23, \mathrm{NS}$ \\
\hline $\mathbf{2 0}^{\text {th }}$ day & 6.76 & 40 & 6.17 & 0.97 & $3.09 \pm 2.67$ & 7.31, & $\mathrm{p}=0.0001, \mathrm{~S}$ \\
\hline $\mathbf{3 0}^{\text {th }}$ day & 4.54 & 40 & 4.21 & 0.66 & $5.31 \pm 5.30$ & 6.34, & $\mathrm{p}=0.0001, \mathrm{~S}$ \\
\hline
\end{tabular}

The mean MSI score in total number of patient was $9.86,9.60,6.76$ and 4.54 on baseline, $10^{\text {th }}$ day, $20^{\text {th }}$ day, and $30^{\text {th }}$ day respectively. Significant result was observed on $20^{\text {th }}$ and $30^{\text {th }}$ day.

Percentage of improvement is 48.27, 62.76 and 53.66 in Dermal, Epidermal and Mixed respectively. By comparing the result of improvement in Dermal, Epidermal and Mixed, it was found that more improvement is observed in Epidermal type than Dermal and Mixed.

Graph 11: Comparison of MSI score with baseline : Dermal

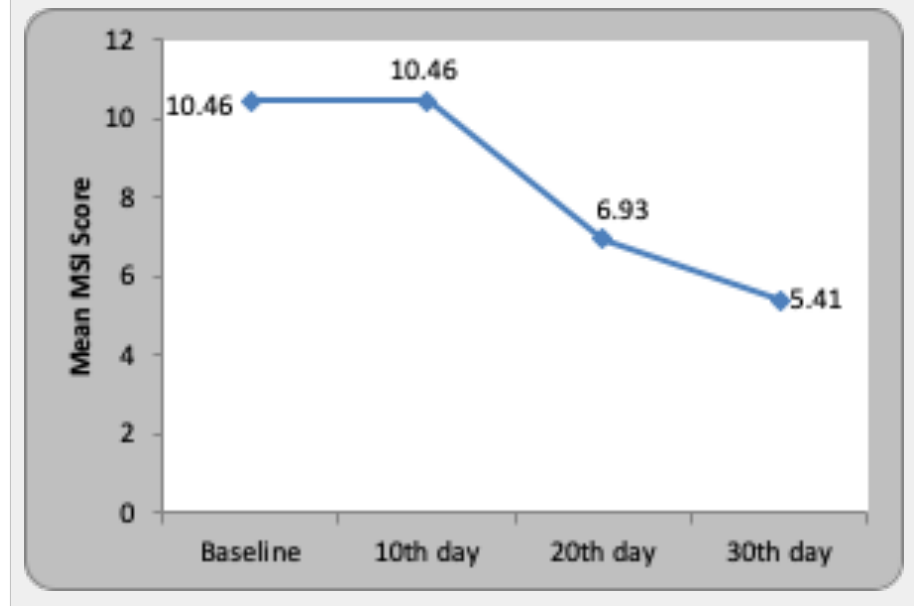

Graph 13: Comparison of MSI score with baseline : Mixed

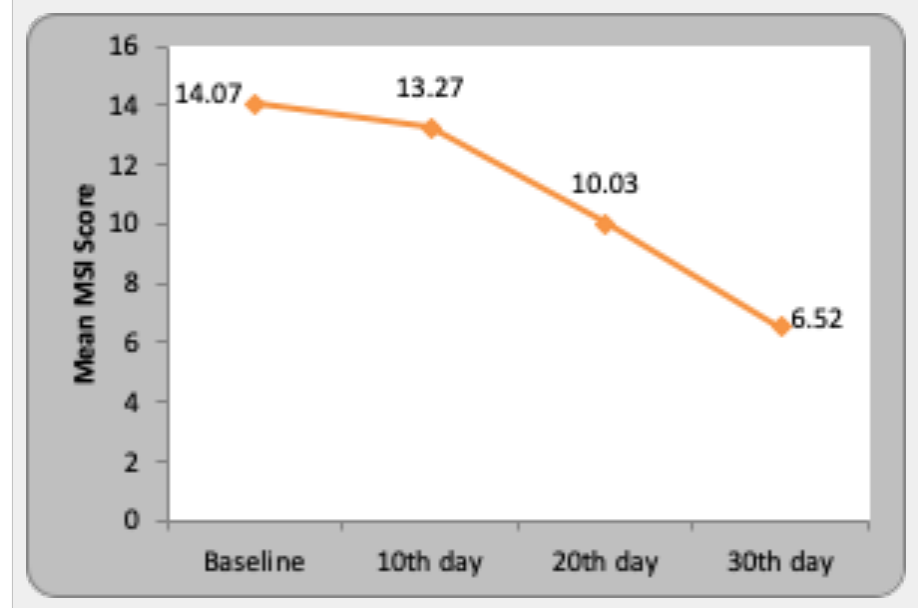

Graph 12: Comparison of MSI score with baseline : Epidermal

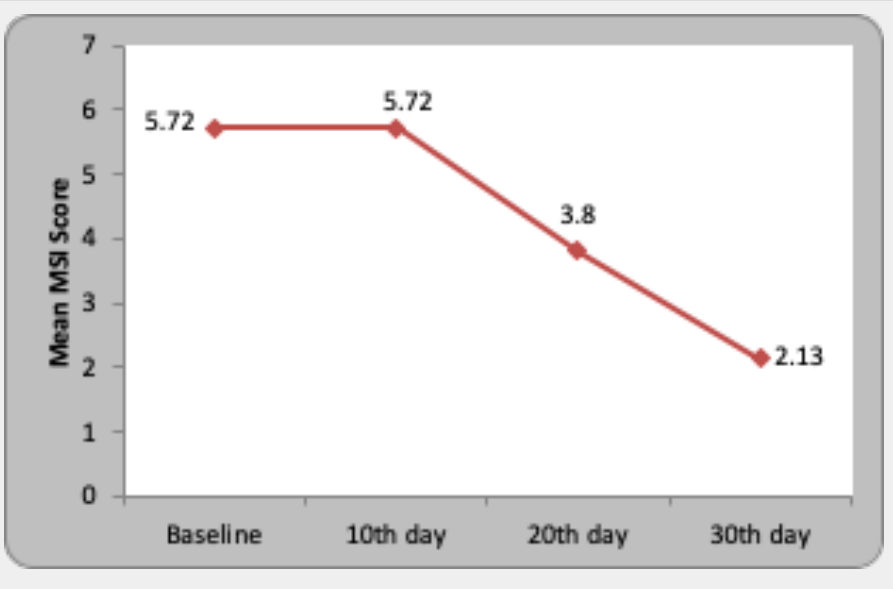

Graph 14: Comparison of data of MSI score with baseline

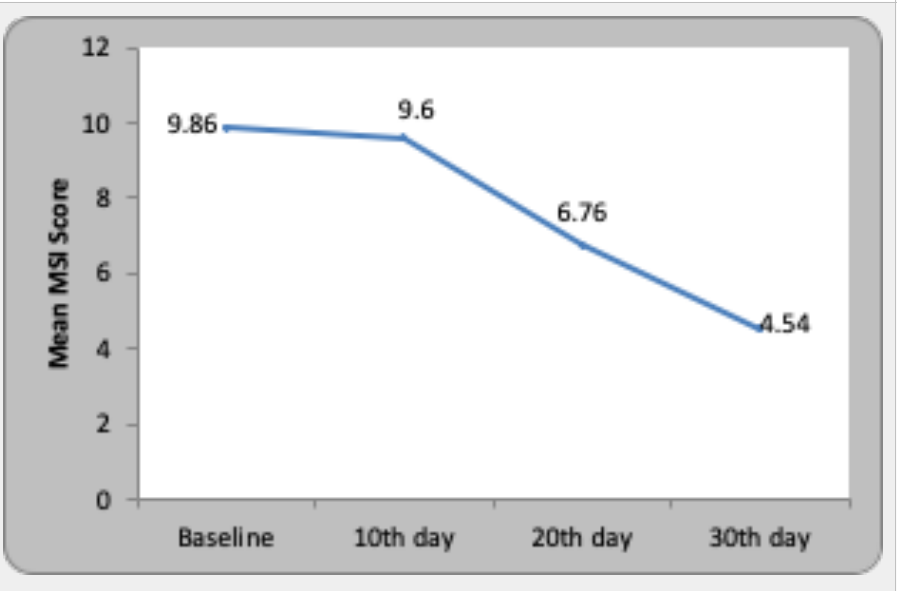




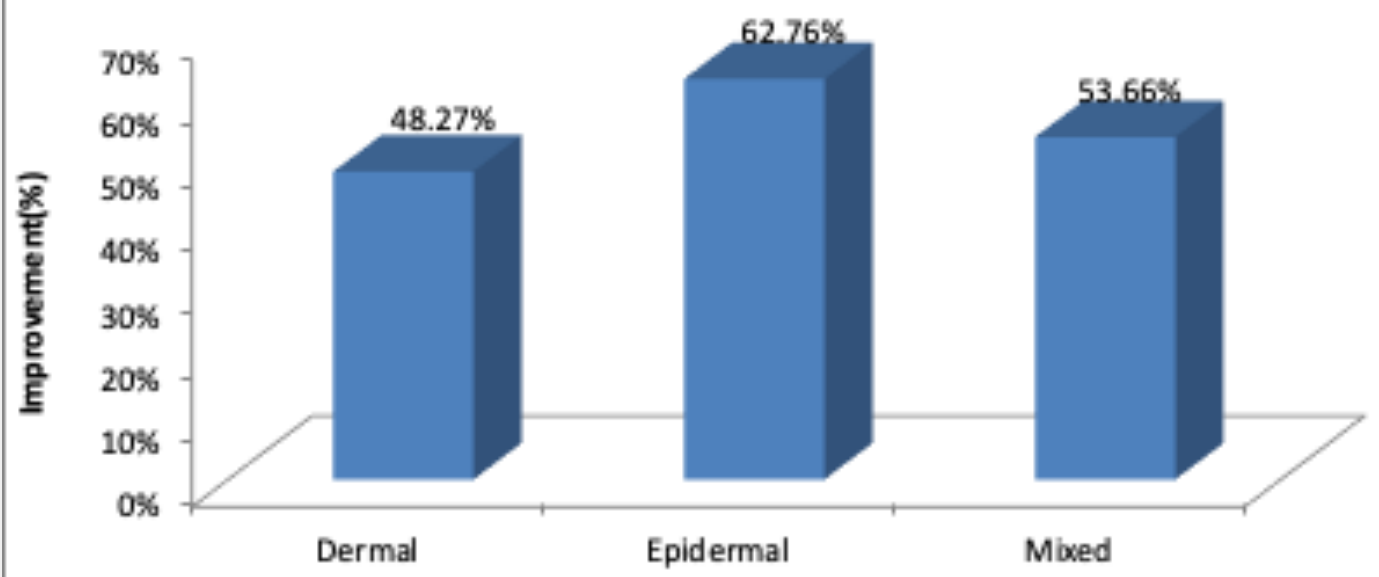

MSI Score

\section{Discussion}

To study the effect of Varuntwak lepa, total 42 patient were selected out of them 40 patients had taken complete treatment.

Melasma commonly manifested in $3^{\text {rd }}$ and $4^{\text {th }}$ decade of life.(18) In our study maximum patient was found from $4^{\text {th }}$ and $5^{\text {th }}$ decade of life that means from the age group of $31-40$ and $41-50$ years.

In this study $85 \%$ were female and as per study of Savita et al also the percentage of female is predominant.(19) Females are more prone to hormonal imbalances which might be the cause.(20) This study didn't showed significant role of family history but in Sanaz et al study its found.(21) By chronicity of disease, $77.5 \%$ patient were found in the range of 1year to 3 year.

Ultraviolet radiation is known factor of melasma.(22) In this study, $45 \%$ patient were having history of regular sun exposure and remaining 55\% patient were not. So it is difficult to correlate sun exposure and melasma. In the similar manner history of regular cosmetic use was also found in $45 \%$ patient but as per Smeeta B K et al sun exposure and cosmetic use showed significant result.(23)

Most of the patient were Rajsik who predominantly took mixed diet, Viruddha ahar and Katulavan rasatmak Ahar. In the classification of Sharirik Prakruti, most of the patient were of Pittakaphaj, Vatapittaj and Pittavataj Prakruti. As per Samprapti Pitta and Vata plays major role in formation of disease.(24) As per Madgundi A K et al study Pittavataj and Vatapittaj Prakruti were more prone to Vyanga.(25)

As per Wood's lamp examination, 35\%, 35\%, and $30 \%$ of Epidermal, Mixed and Dermal were found respectively.In the distribution of lesion, most of patient were of centrofacial pattern and then of malar pattern. It is supported by Angadi S S et al.(26)
Assessment of patient were done on the basis of MSI score.(27) To study the effect of Varun twaka lepa assessment taken on $0^{\text {th }}, 10^{\text {th }}, 20^{\text {th }}$ and $30^{\text {th }}$ day. In all three types, dermal, epidermal and mixed significant result was found on $20^{\text {th }}$ and $30^{\text {th }}$ day. In comparison of three types of melasma more significant result was found in epidermal type.

\section{Probable mode of action of drugs}

The mode of action of drug which was under trial can be understood on the basis of inherent properties of the drug. In literature, Varun is described as Tikta, Kashaya Rasatmak, Laghu, Ruksha Gunatmak and Ushna Viryatmak. Tikta and Kashaya Rasa of Varun encounter Pitta and Rakta Dosha.(28) Kashay Rasa having the properties to bring Savarnata(29) in skin by virtue of which it helps in removing the Twak Vaivarnya and helps to attain normal skin colour. Ushna Virya pacifies Vata and Kapha Dosha. It is also having the properties of Raktadoshahar(30) which help to pacify Sanchit Dosha locally.

As per phytochemical constituent Varun twak contains lupeol, butanol, triterpenoid etc(31) butanol also contains compound like succinic acid, lactic acid. (32) The study which was conducted by Malinowaska et al had shown that lupeol contains the property of stimulating skin repairing process.(33) Lactic acid has exfoliating property, so it is used in chemical peeling for the treatment of melasma it is supported by Singh $\mathrm{R}$ et al.(34) Succinic acid also having anti microbial, anti acne, and anti ageing property.(35) So all these active principle might be act on melasma combinely.

Aja kshir is Madhur and Kashay Rasatmak, Laghu, Snigdha and Shit Viryatmak. Madhur and Kashay Guna subsides the PittaDosha which is the main cause of Vyanga.Snigdha Guna alleviates the Vata Dosha and it is also responsible to maintain the moisture level in skin. Shit virya also act as Pittashamak. All these, combinedly break the Samprapti of Vyanga. 
It is rich in essential fatty acids, minerals, proteins, and multivitamins.(36,37) Among them some minerals like Zinc, Selenium it protect skin from ultraviolet radiation.(38) By the study of Choi Y K et al, it shows that multivitamins inhibited melanogenesis and also act as antioxidant.(39) Hence, all these factors act combinedly and cease the production of Vyanga and subsides its symptoms.

\section{Limitations and Recommendation}

Limitations

- Due to restriction of time, smaller number of patients had taken for study

- Duration of study was short.

Recommendation

- This study can be carried out for longer duration and more patients.

- This study can be conducted by using Varun Twak Lepa as cream base or gel.

\section{Conclusion}

From this study it can be concluded that

- As Vyanga is having similar clinical features with Melasma it can be interrelated with it.

- It is found more in females in Madhyamavastha.

- The most frequently found melasma is Centro-facial pattern.

- Melesma is found in both types of patients i.e. the one who are exposed to sun and also unexposed ones hence we cannot rule out sun exposure to be the causative factor.

- Progress in Melasma Severity Index score indicates that Varun Twaka Lepa is found to be efficient in reducing the severity in pigmentation.

- As per types Varun Twaka Lepa is found to be more efficient in epidermal.

\section{References}

1. Thakaral K K, Sushrut Samhita, Niadansthan, Ch 13/3, Chaukhambha Oriantalia Varansi, First edition 2014; p-842.

2. Murthy K.R.S, Astang Hridayam, Vol 3,Uttarsthana,Ch 31/28-29, Chaukhamba Krishndas Academy,Varanasi, Reprint 2006, p-296.

3. Shukla V, Tripathi R D, Charak Samhita, Sutrastahn 28/11, Vol I, Chaukhamba Sanskrit Pratishthan, Delhi.Reprint 2017; p-430.

4. Thakaral K K, Sushrut Samhita, Niadansthan, Ch 13/45-47, Chaukhambha Oriantalia Varansi, First edition 2014;p-859.

5. Thakaral K K, Sushrut Samhita, Niadansthan, Ch 13/45-47, Chaukhambha Oriantalia Varansi, First edition 2014;p-859.

6. Murthy K.R.S, Madhav Nidan, Ch 55/39, Choukhamba Orientalia, Varanasi, Eighth edition 2007; p-181.

7. Shastri B, Yogaratnakara, Kshudra Roga Chikitsa, Chaukhamba Sanskrit Sansthan, Varanasi, 8 th edition, 2004;283.
8. Murthy K.R.S, Astang Hridayam, Vol 3, Uttarsthana, Ch 31/28-29, Choukhamba Krishndas Academy,Varanasi, Reprint 2006, p-296.

9. Murthy K.R.S, Astang Hridayam, Vol 3, Uttarsthana, Ch 31/28-29, Choukhamba Krishndas Academy,Varanasi, Reprint 2006, p-296.

10. Halder RM, Nootheti PK, Ethnic skin disorders overview. Journal of Am Acad Dermatol 2003; p-48

11. Shah Sidharth N, Paul A M, Billimoria A R, Kamath S A, Munjal Y P, et al. API textbook of medicine vol. 2nd edition 8th 2009 p-1412.

12. Balkrishnan R, Kelly AP, McMichael A and, "Improved Quality of Life with Effective Treatment of Facial Melasma: The Pigment Trial" Journal of Drugs in Dermatology, 2004, Jul-Aug(3) p-377-381.

13. Sialy R, Hassan I, Kaur I, Dash RJ. Melasma in men: A hormonal profile. Journal of Dermatol. 2000; 27:64-5.

14. Achar A, Rathi SK., "Melasma: a clinicoepidemiological study of 312 cases", Indian Journal of Dermatol ,2011;56(4), p-380-382.

15. Balkrishnan, R, Kelly AP, McMichael A and et al, "Improved Quality of Life with Effective Treatment of Facial Melasma: The Pigment Trial" Journal of Drugs in Dermatology, 2004, Jul-Aug(3) p-377-381.

16. Picardo M, Carera M, "New And Experimental Treatments Of Chloasma and Other Hypermelanoses", J of Dermatol Clin, 2007, p-25.

17. Imran Majid, Inamul Haq, Saher Imaran, Abid Keen, Khalid Aziz et al. Proposing melasma severity index: A new, more practical, office-based scoring system for assessing the severity of melasma, Indian J Dermatol, Jan-Feb 2016, 61 (1), 39-44.

18. Dwari BC, Palaian S, Poudel A and Prabhu Smitha "Clinical profile and management pattern of melasma patients in Western Nepal: a hospitalbased study". I journal of Dermatol; jan 2009;7.

19. Angadi Savita, Gowda S, "Management of Vyanga (facial melanosis) with Arjuna Twak Lepa and Panchanimba Churna" Journal of Ayu, Jan- march 2014, vol35, p-50-53.

20. Shah Sidharth N, Paul A M, Billimoria A R, Kamath S A, Munjal Y P, et al. API textbook of medicine vol. 2nd edition 8th 2009; p-1412.

21. Abadchi Sanaz, Naeini F F and Beheshtian E, "Combination of $\mathrm{HQ}$ and fractional $\mathrm{Co} 2$ laser versus hydroquinone monotherapy in melasma treatment: A randomized, single-blinded, split face clinical trial" IJD, 2019, 64, 2:129-135.

22. Shah Sidharth N, Paul A M, Billimoria A R, Kamath S A, Munjal Y P, et al. API textbook of medicine vol. 2nd edition 8th 2009; p- 1412.

23. Smeeta BK and Umapati BC, Cosmetic effect of Charakokta Varnya Mahakashay in Vyanga due to Sunburn(Erythema solare),Journal of Ayurveda and Integrated Medical Sciences, march-apr 2018, p-23-28. 
24. Thakaral K K, Sushrut Samhita, Niadansthan, Ch 13/45-47, Chaukhambha Oriantalia Varansi, First edition 2014;p-859.

25. Madgundi AK, Gotipamul SR and Holkar VN, "Evaluation of the efficacy of mukhakantikar lepa in Hypermelanosis with special reference to Vyanga"; Journal of Ayurveda and Holistic Medicine, May 2014, vol 2, p-31-37.

26. Angadi Savita, Gowda S, "Management of Vyanga (facial melanosis) with Arjuna Twak Lepa and Panchanimba Churna" Journal of Ayu, Jan- march 2014, vol35, p-50-53.

27. Imran Majid, Inamul Haq, Saher Imaran, Abid Keen, Khalid Aziz et al. Proposing melasma severity index: A new, more practical, office-based scoring system for assessing the severity of melasma, Indian J Dermatol, Jan-Feb 2016, 61 (1), 39-44.

28. Tripathi Ravidatta, Ashtang Sangraha, ch 1/36, Choukhambha Sanskrut Pratishthan, Varanasi, reprint 2005, p-15.

29. Tripathi Ravidatta, Ashtang Sangraha, ch 18/18-19, Choukhambha Sanskrut Pratishthan, Varanasi, reprint 2005, p-312.

30. Sharma P, Dhanavatri Nighantu, Choukhamba Orientalia, Varanasi, reprint edition 2008,p-168

31. Sharma M, Reviews on Indian Medicinal Plants, Volume 8, Aravali publishers,2009, p-21.
32. Chanda S, Parakh P, "Phytochemical studies on stem bark of Crataeva nurvala Ham.",Journal of Pharma Research, 2011,4: 401-402.

33. Malinowaska M, Barbara M, Elzbieta S, Jan Ogonowski et al, "New lupeol esters as active substances in the treatment of skin damage",journal pone, 2019, p-1-15.

34. Singh R, Goyal S, Ahmed QR, Gupta N and Sing S, "Effect of $82 \%$ Lactic Acid in Treatment of Melasma",Hindwi, 2014, P-1-8.

35. Theunisse L, Courbes F, "Succinic acid: a promising multi-functional ingredient for cosmetic and personal-care applications",FNA, 2018, p-42-46.

36. Park, Y W, Juarez, M., Ramos, M. and Haenlein, Physico-chemical characteristics of goat and sheep milk. Small Rumin.2007 Res. 68:88-113.

37. Park Y W, Mahoney A.W, Hendricks DG, Macromineral concentrations in milk of two goat breeds at different stages of lactation, 1988, 1:157-165.

38. Leccia M T, Richard M J, Bean J C, Faure H, Monjo AM , et al, "Protective effect of selenium and zinc on UV-A damage in human skin fibroblasts" Photochemistry and photobiology, 1993, p-548-553.

39. Yang Kyu Choi, Yang Kwan Rho, Kwang Ho Yoo, Yun Yong Lim et al, "Effects of vitamin C vs. Multivitamin on melanogenesis, comparative study in vitro and in vivo"2010,2:218-226. 